Our Nature (2011) 9: 128-137

\title{
Transhumance Effect on Husbandry Practices and Physiological Attributes of Chauri (Yak-Cattle) in Rasuwa District
}

\author{
D.K. Chetri*, D.B. Nepali Karki, R. Sah and N.R. Devkota \\ Institute of Agriculture and Animal Sciences (IAAS), TU, Nepal \\ *E-mail:dipeshvet@gmail.com
}

Received: 01.05.2011, Accepted: 27.11.2011

\begin{abstract}
This study was conducted in Rasuwa district, Nepal from 2008 to 2009 in Chauries (3 to 16 years) to analyze the transhumance effect in husbandry practices and physiological vitals. Physiological vitals were evaluated by $2 \times 4$ Factorial CRD with two levels of altitude (high- $3300 \mathrm{~m}$ and low- $1655 \mathrm{~m})$ and four levels of age group $\left(\mathrm{G}_{1^{-}} \leq 6 \mathrm{yrs}, \mathrm{G}_{2^{-}} 7\right.$ to $9 \mathrm{yrs}, \mathrm{G}_{3^{-}} 10$ to $13 \mathrm{yrs}$ and $\mathrm{G}_{4^{-}}>13 \mathrm{yrs}$ ); information regarding husbandry practices were collected from herders $(\mathrm{n}=60)$ using semi-structured questionnaire. Physiological vitals were taken from two altitudes, then analyzed for two- way ANOVA by Mstat- C and survey data by SPSS 16.0. Husbandry practices were found to be almost similar round the year except the matter of herbage supplementation during winter and early parturition. Rectal temperature, respiration rate, pulse rate and DSI showed significant increase $(\mathrm{P}<0.01)$ when animals were at low altitude pasture. Therefore, findings of this study revealed that transhumance system of Chauri management is herders' rational farming approach to make use of available pastures at different altitudes and have a distinct impact on rearing system and animals' physiology.
\end{abstract}

Key words: Transhumance, Chauri,husbandry practices, Dairy Search Index

\section{Introduction}

Chauries, the crosses of yak (Bos grunniens L.) and local hill cow (Bos indicus) or Tibetan yellow cattle (Bos taurus) are confined in high hills and mountainous districts of Nepal, mostly above $2000 \mathrm{~m}$ (Joshi, 1982; Pradhan et al., 2000). Chauries are genetically superior and productive than either parent due to hybrid vigor and are more adaptive to lower altitudes; so, are reared at the intermediate zone of zebu cattle and yak, at around 1500-5000 m on transhumance system (Joshi, 1982; Miller, 1987; Pal et al., 1994; Merkle, 2000; Gurung and McVeigh, 2002). Hybrids with yak are produced with the humpless dwarf cattle of Tibet known as Khirko, Nepalese indigenous hilly cattle as Lulu and Siri hill cattle (Joshi, 1982; 2003).

The husbandry practices and physiological vitals of animals are influenced by various factors such as age, season, environment, work load, physiological condition of animals etc. The effect of age (Xueguang et al., 1994; Sarkar et al., 1999a), lactation (Sarkar et al., 1999b), parturition (Sarkar et al., 1999c) and pack (Mondal et al., 1997) on serum biochemistry of yak and their hybrids had 
been described in Indian and Chinese context. Similarly, variations in biochemical parameters due to sex were also reported (Xueguang et al., 1994; Sen, 1997; Chatterjee et al., 2004a; Chatterjee et al., 2004b). However, information on transhumance influence on various physiological vitals is grossly lacking. Physiological responses to different environments during transhumance too need to be addressed precisely, so that associated problems could be identified in order to help the overall management and uplift the production performances. Initiative had been found to be taken by Sarkar et al. (2000) in Indian yak but is completely lacking in context of yak-cattle or Chauri.

Transhumance is a rule of management, not an exception; so, most of the physiological indices tend to vary during transhumance as altitude, grazing environment and feed type changes abruptly in the process and no single index at specific pasture can work as a reference value applicable to whole pasture range where Chauri naturally remains. This paper describes the transhumance effect on husbandry practices and physiological vitals of chauri.

\section{Materials and methods}

The study was conducted in Dhunche and Syaphru VDCs, Rasuwa district, Nepal, from September, 2008 to March, 2009 in two phases: (a) A field survey on existing Chauri husbandry practices and (b) Biological study with analysis of physiological responses of Chauri under different pasture.

Field survey was conducted using semi-structured questionnaire among 60
Chauri herders to collect information focusing on Chauri rearing system, production performances, health and managemental hindrances, breeding traditions and knowledge, pasture composition and problems in their traditional way of supplementing livelihood system. The laboratory study was laid in $2 \times 4$ factorial CRD with factors (a) Altitudehigh $(3300 \mathrm{~m})$ and low $(1655 \mathrm{~m})$ and $(\mathrm{b})$ Age groups- $G_{1}(\leq 6 \mathrm{yrs}), G_{2}(7-9$ yrs $), G_{3}$ (10- 13 yrs) and $\mathrm{G}_{4}(>13 \mathrm{yrs}) .28$ Chauries of 3-16 years age were selected randomly from different Chauri herds, grouped into four different age groups as $\mathrm{G}_{1}, \mathrm{G}_{2}, \mathrm{G}_{3}$ and $\mathrm{G}_{4}$. Then, these animals were used as sample source both at high and low altitude pasture. Physiological responses like Rectal temperature $\left({ }^{\circ} \mathrm{C}\right)$, Respiration rate $(\mathrm{bpm})$ and Pulse rate (bpm) were recorded twice daily at 7.00-8.00 morning and 4.00-5.00 evening regularly for three days and their average were used for analysis. Evening observations were recorded about 30 minutes following return to eliminate the grazing effect. From these data, Dairy Search Index (DSI) was determined by following equation for each animal as described by Bonsma (1949):

$\mathrm{DSI}=\mathrm{DSI}=0.5 \times \mathrm{X}_{1} / \mathrm{X}+0.2 \times \mathrm{Y}_{1} / \mathrm{Y}+0.3$ $\times \mathrm{Z}_{1} / \mathrm{Z}$,

Where $X_{1}, Y_{1}$ and $Z_{1}$ are the observed rectal temperature $\left({ }^{\circ} \mathrm{C}\right)$, respiration rate and pulse rate, respectively. $\mathrm{X}, \mathrm{Y}$ and $\mathrm{Z}$ are normal rectal temperature, respiration rate and pulse rate which are $38.33{ }^{\circ} \mathrm{C}, 23 \mathrm{bpm}$ and $60 \mathrm{bpm}$, respectively.

Data were analyzed for ANOVA by Mstat- C (version 1.3 Michigan University, 1994). Mean comparison were done by using DMRT and LSD at 5\% level of 
D.K. Chetri, D.B. Nepali Karki, R. Sah and N.R. Devkota/Our Nature (2011) 9:128-137

significance. Survey data were analyzed by SPSS 16.0 Stastical Software Package, 2007 (SPSS Inc., Chicago).

\section{Results and discussion Migration Tract}

Transhumance, seasonal migration of herds between different but complementary ecological points, summer pastures in the mountains and winter pastures in the lowlands, is key grazing pattern and it is a recurrent feature of indigenous grazing management systems in Syaphru and Dhunche VDCs, Rasuwa, Nepal, mainly to exploit seasonal availability of pasture. Transhumance system, characterized by diversity and mobility to minimize risk in unpredictable conditions is an ecological reality and a good indicator of rangeland health. Based on the climatic conditions, ritual beliefs, herbage need and availability of pasture land; the herders have established different herding tract and pastures for grazing their Chauries. The animals move towards high altitude alpine pastures in the monsoon season and to lower pastures, fallow lands or community forest near settlement during the winter (Fig. 1). In Dhunche, the farmers settle in the lowland and herd their livestock in vertical transhumance from the community forest (about $1700 \mathrm{~m} \mathrm{msl}$ ) surrounding their settlements in winter to Lauribinayak pasture (about $4300 \mathrm{~m}$ in altitude) in summer. In Syaphru, the farmers settle close to their community oak forestry (about 1800 $\mathrm{m}$ ) for winter grazing and herd their Chauri herds in ascending transhumance to Lauribinayak pasture for summer grazing.

\section{Herd and feeding management information}

Chauri herding is the tradition, farmers being on this herding profession since long back, some herders gave history of Yak and Chauri herding since $8^{\text {th }}$ generation back but herd size are in decreasing trend in comparison to figures, a decade back. Most herders were found to have less than 20 animals and only few farmers with more than 30 animals (Tab. 1). The decreasing herd size was mainly because of family splitting and decreasing available pasture lands. McVeigh (2004) described similar herd size and its decreasing trend in Lantang valley, Rasuwa. Similarly, Pande (2004) described average herd size of 17.60 in Sindhupalchowk district with decreasing trend from 20 to 25 animals five years back but Shrestha et al. (1996) reported 6.5 animals herd size. Chauries were housed on open roof system, with some temporary fencing only on some predator prone regions, round the year on absolute grazing with no supplementations except offering a handful of salt once daily. But, in winter, almost half farmers were found to supplement extra fodders like straw, hay, vegetable leftovers, whey etc. to milking animals. Most herders were found to supplement good quality feeds to milking animals as succulent roughages, cereals and extra salts as Joshi (1982, 2003), Pradhan et al. (2000) and Pande (2004) described earlier.

\section{Production performances and reproductive characteristics \\ Average first calving age of chauri is}


D.K. Chetri, D.B. Nepali Karki, R. Sah and N.R. Devkota/Our Nature (2011) 9:128-137

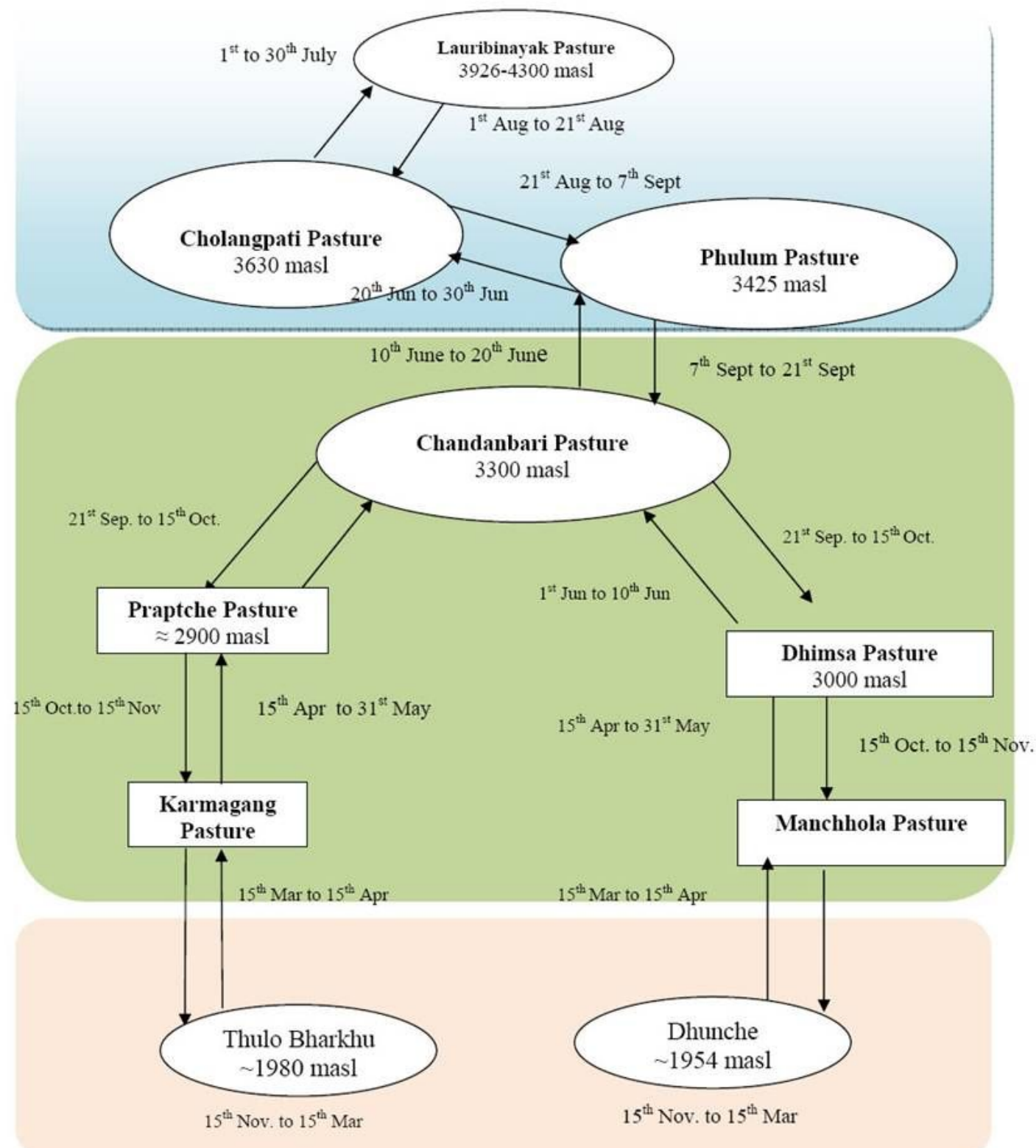

Figure 1. Transhumance tract and its traditional calendar in Dhunche and Syaphru VDCs, Rasuwa district.

extrapolated to be 3.07 years with majority of animals to calve first at 3 years of age and more than half was found to have lactation period of 6 to 7 months. The lactation length is extremely short in Yak and Chauri because of the harsh environmental condition and extreme feed scarcity they have to cope with, on low 
altitude pasture during winter. Animals were reported to lose up to $20-25 \%$ of their body weight in winter pasture (FAO, 2003). Similar studies of Yak and Chauri by Joshi et al. (1994) and Pande (2007) described almost same figure of first calving age as 35 months and 3 years but they accounted average lactation period to be 254 to 400 days. However, Shrestha et al. (1996) described a higher first calving age (3.94 \pm 0.09 years) of Chauri. Animals were found to be in production for 20 to 22 years and were weaned at less than 15 days age. If calves are expected to be superior and herder wishes to keep it as future chauri, then he weans at around 4 months. Similarly, majority of animals were found to have 13 to 14 months calving interval as was described earlier by Joshi et al. (1994), Shrestha et al. (1996) and Pande (2007) for dimzo and urang Chauri. However, Paudyal (1995) and Neopane et al. (1999) had described calving interval of 1.7 years and $1.53 \pm 0.48$ years respectively, quite longer than this finding. Regarding production performances, Chauries were observed to produce 1 to 4 liters of milk; which are all purchased and used by Cheese Production Center from Baisakh (April/May) to Kartik (Oct/Nov) for cheese and butter production; milk on remaining months are used for household consumption, for ghee, butter and chhurpi (hard cheese) preparation (Tab.2).

\section{Health care and management}

Herders were found to have basic knowledge on common diseases such as FMD, BQ, HS, and Mastitis; were aware on importance of anthelmintics use but none herders were found to drench their herds in routine (Tab.3). Similar facts had been reported by Degen et al. (2007) with only one Yak and Chauri herder to practice drenching and dipping twice yearly in Mustang district, Nepal. Farmers were in favor of indigenous knowledge of herbal preparation as ectoparasiticidal remedies and were found to rely on different locally available plant extracts for this purpose. Ectoparasites are the problem when Chauries come down to lower altitude pasture in winter season and share grazing land with low altitude livestock species. Traditional healers or Amchi were well accepted livestock worker in Chauri herding highlands, where access of veterinarians and paraprofessionals were hard to expect, which might be the fact that none animals were found vaccinated against any diseases. Degen et al. (2007) also reported similar facts about vaccination in Yak and Chauri herds in Mustangi herders with no animals vaccinated against any disease.

Table 1. Information on herd and feeding management of Chauri $(n=60)$ in Rasuwa, 2008.

\begin{tabular}{llc}
\hline Description & Categories & $\begin{array}{c}\text { No. of } \\
\text { Farmers (\%) }\end{array}$ \\
\hline $\begin{array}{l}\text { History of } \\
\text { chauri keeping }\end{array}$ & From generations & $59(98.33)$ \\
& back & $01(01.67)$ \\
\hline Herd size & Above 30 bars & $18(30.00)$ \\
& $20-30$ & $16(27.00)$ \\
& Below 20 & $26(43.00)$ \\
\hline Shed used & Open roof system & $56(93.33)$ \\
& Temporary shed & $04(06.67)$ \\
\hline Feeding & Only grazing & $52(86.67)$ \\
management & Grazing, cereals, & \\
& whey, brewery & $08(13.33)$ \\
\hline $\begin{array}{l}\text { Feeding in lean } \\
\text { season }\end{array}$ & Grazing & $32(53.33)$ \\
& Straw/hay, whey & $28(46.67)$ \\
\hline $\begin{array}{l}\text { Supplementation No } \\
\text { for increasing } \\
\text { milk yield }\end{array}$ & Green roughages + & $26(43.33)$ \\
\hline
\end{tabular}


D.K. Chetri, D.B. Nepali Karki, R. Sah and N.R. Devkota/Our Nature (2011) 9:128-137

Table 2. Information on production performances, reproductive characteristics and postproduction use of Chauri ( $\mathrm{n}=60)$ in Rasuwa, 2008.

\begin{tabular}{lll}
\hline Description & Categories & $\begin{array}{c}\text { No. of farmers } \\
\text { (\%) }\end{array}$ \\
\hline First & 3 years & $51(85.00)$ \\
calving age & 4 years & $09(15.00)$ \\
\hline Lactation & 6 to 7 months & $35(58.33)$ \\
period & 7 months & $12(20.00)$ \\
& Above 7 months & $13(21.67)$ \\
\hline Average & Above 22 years & $03(05.00)$ \\
productive & 20 to 22 years & $41(68.33)$ \\
age & Below 20 years & $16(26.67)$ \\
\hline Weaning & Above 1.5 months & $13(21.67)$ \\
age & 0.5 to 1.5 months & $19(31.67)$ \\
& Below 0.5 months & $28(46.67)$ \\
\hline Calving & $13-14$ months & $55(91.67)$ \\
interval & $15-16$ months & $05(08.33)$ \\
\hline $\begin{array}{l}\text { Average } \\
\text { milk yield }\end{array}$ & 2 to 4 liters/day 3 liters/day & $29(48.33)$ \\
per day & 1 to 2 liters/day & $20(33.33)$ \\
Milk use & To DDC & $11(18.33)$ \\
pattern & (April/May- & $60(100.00)$ \\
& Oct/Nov) and as & \\
& ghee and Chhurpi in & \\
\hline
\end{tabular}

Table 3. Distribution of variables associated with health care and consciousness about diseases and vaccines of Chauri ( $\mathrm{n}=60)$ in Rasuwa, 2008.

\begin{tabular}{lll}
\hline Description & Categories & $\begin{array}{c}\text { No. of } \\
\text { farmers(\%) }\end{array}$ \\
\hline $\begin{array}{l}\text { Knowledge on } \\
\text { diseases }\end{array}$ & Yes & $39(65.00)$ \\
common to Chauri & No & $21(35.00)$ \\
\hline Anthelmintics use & No & $07(11.67)$ \\
pattern & Allopathic & $14(23.33)$ \\
& Ethno-herbal & $19(31.67)$ \\
& Both & $20(33.33)$ \\
\hline Acaricide use & Malathion and & \\
pattern & others & $15(25.00)$ \\
& Ethno-herbal & $45(75.00)$ \\
\hline Diseases and & Veterinarians and & \\
problems consulted & Para-veterinarians & $03(05.00)$ \\
and treated with & Amchi or & \\
& Traditional healers & $22(36.67)$ \\
& Both & $35(58.33)$ \\
\hline Knowledge on & Yes & $05(08.33)$ \\
vaccines & No & $55(91.67)$ \\
\hline
\end{tabular}

\section{Herders' knowledge on pasture species and sires}

All herders had excellent knowledge on different poisonous and milk off- flavoring plants common on their pasture lands. The pasture species those are poisonous to Chauri and other livestock species, as identified by herders, are Sirmorba, Chyom, Fern, Mushroom, Murba and Gandhe. Similarly, Titepati (Artemisia biennis), Chiraito (Swertia sp.), Chyom, Bojo (Acorus calamus), Gandhe (Ageratum houstonianum), Jimbu (Allium fasciculatum) etc. are the common milk tainting plants. Tibetan yellow cattle (Bhelang in local term) were preferred more as a sire for Yak and Chauri breeding, but use of local hilly bull is being common because of ease of availability (Tab.4). The availability of pure Tibetan yellow cattle is decreasing after closure of Tibetan border, so sharing of breeding sires among different Chauri herds are common practice in Syaphru and Dhunche VDCs. Herders pointed out pasture land deterioration and increased disease prevalence as the main problem.

\section{Basic physiological vitals}

Mean rectal temperature, respiration rate, pulse rate and DSI were found significantly higher $(\mathrm{P}<0.01)$ in animals at low altitude pasture (Tab. 5). This might be due to the fact that low altitude pasturelands were atypical to Chauri from temperature view point which develops some sort of stress and this condition is again aggravated by prolonged shortage of herbage biomass. Therefore, animals were reported to lose up to $20-25 \%$ of their body weight at low altitude pasture during winter season (FAO, 2003). It is obvious that any imbalance in 
D.K. Chetri, D.B. Nepali Karki, R. Sah and N.R. Devkota/Our Nature (2011) 9:128-137

heat production and loss, which cannot be precisely handled by the thermoregulatory mechanism, is reflected by an increase in body temperature and then increase in other physiological responses to cope with accumulated heat in body.

Table 4. Distribution of variables associated with knowledge on poisonous plants, bull preferences and common husbandry constraints of Chauri $(n=60)$ in Rasuwa, 2008.

\begin{tabular}{|c|c|c|}
\hline Description & Categories & $\begin{array}{c}\text { No. of farmers } \\
(\%)\end{array}$ \\
\hline $\begin{array}{l}\text { Knowledge on } \\
\text { poisonous plants }\end{array}$ & $\begin{array}{l}\text { Yes } \\
\text { No }\end{array}$ & $\begin{array}{c}60(100.00) \\
-\end{array}$ \\
\hline $\begin{array}{l}\text { Knowledge on milk } \\
\text { tainting plants }\end{array}$ & $\begin{array}{l}\text { Yes } \\
\text { No }\end{array}$ & $\begin{array}{c}60(100.00) \\
-\end{array}$ \\
\hline $\begin{array}{l}\text { Type of bull used } \\
\text { for breeding }\end{array}$ & $\begin{array}{l}\text { Tibetan yellow } \\
\text { cattle or } \\
\text { Bhelang } \\
\text { Local bull } \\
\text { Both }\end{array}$ & $\begin{array}{l}43(71.67) \\
08(13.33) \\
09(15.00)\end{array}$ \\
\hline $\begin{array}{l}\text { Constraints in } \\
\text { Chauri husbandry }\end{array}$ & $\begin{array}{l}\text { Pasture land } \\
\text { scarcity and } \\
\text { diseases } \\
\text { Bull scarcity } \\
\text { and increasing } \\
\text { poisonous } \\
\text { plants }\end{array}$ & $\begin{array}{l}44(73.33) \\
16(26.67)\end{array}$ \\
\hline
\end{tabular}

Similar to this finding, Sarkar et al. (2000) described higher rectal temperature in moderately cold humid season or low altitude pasture in yak. Li (1981) too described similar facts of rising body temperature above an ambient temperature of $13^{\circ} \mathrm{C}-16^{\circ} \mathrm{C}$ and when it reaches $20^{\circ} \mathrm{C}$, yak looks for shade without moving, grazing, drinking or ruminating. But, at the other extreme, it can feed and move normally at ambient temperatures ranging as low as $30^{\circ} \mathrm{C}$ to $-40^{\circ} \mathrm{C}$. With respect to respiration rate, this finding is in agreement with Sarkar et al. (2000) who described a significant rise in respiration rate in moderately cold humid season or low altitude pasture range in yak. Li (1975) observed respiration rate 20-30 per minute at $13^{\circ} \mathrm{C}$, but above that temperature it increased rapidly in yak.

Table 5. Mean rectal temperature, respiration rate, pulse rate and dairy search index value of Chauri in relation to altitude and age groups in Rasuwa, 2008 $(n=28)$.

\begin{tabular}{|c|c|c|c|c|}
\hline \multirow[b]{2}{*}{ Treatments } & \multicolumn{4}{|c|}{ Parameters } \\
\hline & $\begin{array}{c}\text { Rectal } \\
\text { Temp. } \\
\left({ }^{\circ} \mathbf{C}\right)\end{array}$ & $\begin{array}{l}\text { Resp. } \\
\text { Rate } \\
(/ \mathrm{min})\end{array}$ & $\begin{array}{c}\text { Pulse } \\
\text { Rate } \\
(/ \mathrm{min})\end{array}$ & (DSI) \\
\hline \multicolumn{5}{|l|}{$\overline{\text { Altitude }}$} \\
\hline High (3365 m) & $38.69^{\mathrm{a}}$ & $19.78^{\mathrm{a}}$ & $57.1^{\mathrm{a}}$ & $0.96^{\mathrm{a}}$ \\
\hline Low (1655 m) & $38.97^{\mathrm{b}}$ & $48.37^{\mathrm{b}}$ & $72.30^{\mathrm{b}}$ & $1.29^{\mathrm{b}}$ \\
\hline$P$ value & $* *$ & $* *$ & $* *$ & $* *$ \\
\hline \multicolumn{5}{|l|}{ Age } \\
\hline G1 (Upto 6 yrs) & 38.77 & 33.55 & 64.52 & 1.12 \\
\hline G2 (7-9 yrs) & 38.85 & 33.02 & 64.84 & 1.12 \\
\hline G3 (10-13 yrs) & 38.80 & 33.66 & 64.61 & 1.12 \\
\hline G4 (>13 yrs) & 38.90 & 36.05 & 64.98 & 1.15 \\
\hline$P$ value & Ns & Ns & Ns & Ns \\
\hline \multicolumn{5}{|c|}{ Altitude Age combined effect } \\
\hline High, G1 & 38.67 & 19.54 & 57.61 & 0.96 \\
\hline High, G2 & 38.69 & 19.39 & 57.68 & 0.96 \\
\hline High, G3 & 38.66 & 20.00 & 56.82 & 0.96 \\
\hline High, G4 & 38.73 & 20.18 & 56.57 & 0.96 \\
\hline Low, G1 & 38.87 & 47.57 & 71.43 & 1.28 \\
\hline Low, G2 & 39.01 & 46.64 & 72.00 & 1.28 \\
\hline Low, G3 & 38.94 & 47.32 & 72.39 & 1.28 \\
\hline Low, G4 & 39.06 & 51.93 & 73.39 & 1.33 \\
\hline$P$ value & Ns & Ns & Ns & Ns \\
\hline CV\% & 0.34 & 12.52 & 3.94 & 3.75 \\
\hline
\end{tabular}

**Highly Significant at $\mathrm{P}<0.01$, Ns non significant at $\mathrm{P}>0.05$, Means with different letter superscripts within column within each treatment differ significantly at $\mathrm{P}<0.05$.

Zhang (1989) reported a respiration rate in adult yak of $80 / \mathrm{m}$ at $28^{\circ} \mathrm{C}, 49 / \mathrm{m}$ at $10^{\circ} \mathrm{C}$ and $25 / \mathrm{m}$ at $5^{\circ} \mathrm{C}$. Pulse rate in this study was observed to differ significantly in high and low altitude animals, which is in agreement with Sarkar et al. (2000) in yak. However, Zhao (1982) reported highest 
pulse rate in June, i.e., at high altitude on transhumance system and a gradual decline after the warm season ends. Dairy search Index (DSI) figure too was in agreement with Sarkar et al. (2000) who described a significant increase in DSI value in yak at low altitude pasture indicating a decrease in thermal adaptability as it was much deviated from ' 1 ' as compared to value at high altitude pasture.

However, all the physiological responses were found to vary nonsignificantly $(\mathrm{P}>0.05)$ and were within the normal physiological range as referenced for bovids with respect to age group of chauri and in all treatment combinations.

\section{Conclusion}

Current Chauri husbandry needs a rational intervention in order to move this traditional farming approach in line with $21^{\text {st }}$ century's livestock keeping principle. Physiological attributes are a matter of great variation during transhumance and figure obtained from this study can work as a reference data for chauri health management and therapeutics in Nepalese context.

\section{Acknowledgements}

The Global Future Institute (GFI), USA and Animal Health Training and Consultancy Services (AHTCS), Nepal is heartily acknowledged for their financial support without which, this work would not have been accomplished.

\section{References}

Bonsma, J. 1949. Breeding cattle for increased adaptability to tropical and subtropical environment. Journal Agricultural Science 39: 204-221.
Chatterjee, A., R. Pourouchottamane, D.N. Das and M. Sarkar 2004a. Some serum biochemical parameters in yak (Poephagus grunniens). Indian Journal of Animal Science 74(1): 53-55.

Chatterjee, A., R. Pourouchottamane, M. Sarkar and M. Bhattacharya 2004b. Serum macro-mineral profile in female yak grazed on winter pasture. In: Yak production in central Asian highlands Proceedings of the Fourth International Congress on Yak, 2004- Chengdu, China. (Eds. Z. Jincheng, Z. Xiangdong, H. Jianlin and C. Zhihua). International Livestock Research Institute (ILRI), Nairobi, Kenya

Degen, A.A., M. Kam, S.B. Pandey, C.R. Upreti, S. Pandey and P. Regmi 2007. Transhumant pastoralism in the lower Mustang district. Nomadic peoples 11(2): 57-85.

FAO 2003. The $y a k, 2^{\text {nd }}$ edition. (Eds. G. Wiener, J. Han and R. Long). Regional office for Asia and the Pacific, RAP Publication, Food and Agriculture Organization, Bangkok. pp. 61-82.

Gurung, G. and C. McVeigh 2002. Pastoral management and yak rearing in Manang's Nar and Phu valley. In: Yak production in central Asian highlands. Proceedings of the $3^{\text {rd }}$ International congress on yak held in Lhasa, P.R. China, 4-9 Sept 2000. (Eds. H. Jianlin, C. Richard, O. Hannotte, C. McVeigh and J.E.O. Rege). International Livestock Research Institute (ILRI), Nairobi, Kenya. pp. 104-119.

Joshi, D.D. 1982. Yak and Chauri husbandry in Nepal. HMG Press, Kathmandu, Nepal. 145p.

Joshi, D.D. 2003. Yak in Nepal. In: The yak, $2^{\text {nd }}$ edition. (Eds. W. Gerald, J. Han and R. Long). Food and Agriculture Organization, Regional office for Asia and the Pacific, RAP Publication, Bangkok, Thailand. pp. 316-322.

Joshi, D.D., P.N. Lund, D.J. Miller and S.K. Shrestha 1994. Yak production in Nepal. In: Yak production in central Asian highlands (Eds. Z. Rongchang, H. Jianlin and W. Jianping). Proceedings of the $1^{\text {st }}$ international congress on yak held in Lanzhou, P.R. China, 4-9 September 1994. Supplement of J. Gansu Agric. Uni., Lanzhou. Printing house of Gansu economic management cadre institute, China. pp. 105-112. 


\section{D.K. Chetri, D.B. Nepali Karki, R. Sah and N.R. Devkota/Our Nature (2011) 9:128-137}

Li, C. 1975. Determination of physiological and biochemical indexes in yak. Journal of Chinese Animal Science 6: 29-31.

Li, S. 1981. The preliminary observation on yak's heat resistance. Journal of China Yak 2: 1-4.

McVeigh, C. 2004. Himalayan herding is alive and well: the economics of pastoralism in the Langtang valley. Nomadic peoples 8(2): 107-124.

Merkle, R. 2000. Nomadism: A socioecological mode of culture. In: Yak production in central Asian highlands (Eds. H. Jianlin, C. Richard, O. Hannotte, C. McVeigh and J.E.O. Rege). Proceedings of the $3^{\text {rd }}$ international congress on yak held in Lhasa, P.R. China, 4-9 September, 2000. International Livestock Research Institute (ILRI), Nairobi, Kenya. pp. 128-133.

Miller, D.J. 1987. Yaks and grasses: pastoralism in the Himalayan countries of Nepal and Bhutan and Strategies for sustained development. University of Montana, Missoula, Montana. (Masters Thesis)

Mondal, D.B., R.N. Pal, S.K. Barari, T.K. Mohanty and U.A. Nandankar 1997. Effect of normal haematophysiology due to pack on yaks- a preliminary study. In: Yak production in central Asian highlands (Eds. Y. Rongzhen, H. Xingtai and L. Xiaolin). Proceedings of the $2^{\text {nd }}$ Int. Congress on Yak held in Xining, China, 1-6 Sep., 1997. Qinghai People's Publishing House, Xining, P.R. China. pp. 204-207.

Neopane, S.P., P.K. Pokharel and S. Shrestha 1999. Evaluation of productive performance of Yak at Solukhumbu. In: Proceedings of the $3^{\text {rd }}$ National Workshop on Liv. and Fisheries Research in Nepal (Eds. S.P. Neopane and R.C. Khanal). 2628 June, 1999. NASRI, Nepal.

Pal, R.N., S.K. Barari and D. Biswas 1994. Yak (P. grunniens) husbandry in India. In: Yak Production in Central Asian Highlands (Eds. Z. Rongchang, H. Jianlin and W. Jianping). Proceedings of the $1^{\text {st }}$ Int. congress on yak held in Lanzhou, 4-9 Sep., 1994. Supplement of J. Gansu Agric. Uni., Lanzhou, China. pp. 16-21.

Pande, R.S. 2004. Chauri production systems in upper slope areas, Sindhupalchok, Nepal. In: Yak Production in Central Asian Highlands (Eds. Z. Jincheng, Z. Xiangdong, H. Jianlin and C. Zhihua). Proceedings of the Fourth International Congress on Yak, 2004- Chengdu, China.
International Livestock Research Institute (ILRI), Nairobi, Kenya.

Pande, R.S. 2007. Yak farming in Nepal. Nepalese Agricultural Information. Kathmandu, Nepal. http://atoz-nepal.blogspot.com/2007/03/yakfarming-in-nepal.html [Retrieved $4^{\text {th }}$ Sep., 2009].

Paudyal, R.M. 1995. Basic physiological parameters of the Yak and Chauri: A review. Veterinary Review 10(2): 10-14.

Pradhan, S.L., D.K. Hitchcock and D. Miller 2000 Yak hybridization in the upper slope region of Nepal: A community resource management strategy. In: Yak Production in Central Asian Highlands (Eds. H. Jianlin, C. Richard, O. Hannotte, C. McVeigh and J.E.O. Rege). Proceedings of the $3^{\text {rd }}$ Int. Congress on Yak in Lhasa, P.R. China, 4-9 September, 2000. International Livestock Research Institute (ILRI), Nairobi, Kenya. pp. 146-157.

Sarkar, M., B.C. Das, D.B. Mondal and A. Chatterjee 2000. Physiological responses of yak under different environments. In: Yak Production in Central Asian Highlands (Eds. H. Jianlin, C. Richard, O. Hannotte, C. McVeigh and J.E.O Rege). Proceedings of the $3^{\text {rd }}$ International Congress on yak held in Lhasa, P.R. China, 4-9 September, 2000. International Livestock Research Institute (ILRI), Nairobi, Kenya. pp. 388-392.

Sarkar, M., B.C. Das, D.B. Mondal, D.N. Das, T.K. Mohanty, B.P. Singh, R.N. Pal and S. Ray 1999c. Haemogram in yak ( $P$. grunniens) during parturition. Indian Journal of Animal Science 69(1):32-33.

Sarkar, M., B.C. Das, D.N. Das, D.B. Mondal and T.K. Mohanty 1999a. Studies on haematology of yaks ( $P$. grunniens) from birth to one year of age. Indian Journal of Animal Science 69(10): 800802.

Sarkar, M., D.N. Das, B.C. Das, D.B. Mondal, T.K. Mohanty and B.P.S. Yadav 1999b. Influence of lactation on the haemogram of yak ( $P$. grunniens) Indian Journal of Animal Science 69(8): 588-589.

Sen, M. 1997. Physiological and biochemical parameters and potassium phynotype in the blood of Qinghai White Yak. In: Yak production in central Asian highlands (Eds. Y. Rongzhen, H. Xingtai and L. Xiaolin). Proceedings of the $2^{\text {nd }}$ 
D.K. Chetri, D.B. Nepali Karki, R. Sah and N.R. Devkota/Our Nature (2011) 9:128-137

International Congress on Yak held in Xining, P.R. China, 1-6 September 1997. Qinghai Peoples Publishing House, Xining, P.R. China. pp. 210212.

Shrestha, B.S., K.S. Kshatri, N.P. Shrestha and L. Sherchand 1996. Morphological characteristics and productive and reproductive performance of Yak/Nak. In: Proceeding of the $1^{\text {st }}$ National Workshop on Livestock/Fisheries Research in Nepal (Eds. B.S. Kuwar and H.R. Shrestha). May 7-9, 1996. NASRI, Lalitpur, Nepal. pp. 73-80.

Xueguang, M., W. Guihua, Q. Qi, Xinai and S. Boaxin 1994. The physiological and biochemical constants of Xinjiang Bayingilon Yak. In: Yak production in central Asian highlands (Eds. Z. Rongchang, H. Jianlin, W. Jianping and C. Yanhong). Proceeding of the $1^{\text {st }}$ International Congress on Yak in Gansu Agriculture University, China, 1-6 August, 1994. Supplement of J. Gansu Agric. Uni., Lanzhou. Printing house of Gansu Economic Management Cadre Institute, China. pp. 272-275.

Zhang, R. 1989. Yak of China. Lanzhou- Gansu Science and Technology Publishing House. pp. 75-194.

Zhao, B. 1982. Study on the three physiological indexes of yak. Journal of China Yak 4: 24-30. 